\title{
Biopsy of Soft Palate
}

National Cancer Institute

\section{Source}

National Cancer Institute. Biopsy of Soft Palate. NCI Thesaurus. Code C51585.

Removal of tissue from the soft palate for microscopic examination. 